\title{
Growth beyond Gibrat: firm growth processes and strategies
}

\author{
Erik Stam
}

Accepted: 26 May 2010/Published online: 7 July 2010

(C) The Author(s) 2010. This article is published with open access at Springerlink.com

\begin{abstract}
Firm growth studies have been focused on the question of whether firm growth is independent of firm size. This shadow of Gibrat's Law has drawn attention to the randomness in firm growth. However, it has also clouded relevant research avenues that enquire into the role of firm growth processes and strategies. This paper takes stock of the current state of the art of firm growth studies in small business economics, and makes a plea for more specific research approaches that highlight the nature of the firm, organization, and growth paths. This rejuvenation of firm growth studies comprises a search for necessary mechanisms and contingent conditions for the growth of firms.
\end{abstract}

Keywords Firm growth - Growth processes . Strategy · Gibrat's Law

JEL classifications $\quad$ D21 $\cdot$ L22 $\cdot$ L25 $\cdot$ L26 $\cdot$ M13

E. Stam $(\bowtie)$

Utrecht School of Economics, Utrecht University, Utrecht, The Netherlands

e-mail: e.stam@uu.nl

E. Stam

Scientific Council for Government Policy (WRR), The Hague, The Netherlands

E. Stam

Centre for Technology Management, University

of Cambridge, Cambridge, UK

\section{Introduction}

Firm growth has been a central topic in Small Business Economics ever since its inception. It has been a central topic in the fields of industrial organization (Evans 1987; Coad 2009), small business economics (Storey 1994; Vivarelli 2007), and entrepreneurship (Davidsson 1991; Davidsson et al. 2006) for decades. The increasing availability of data on the growth processes of new and/or small and medium-sized firms provides the foundation for considerably sharpening our understanding of firm growth. This enables us to go beyond the observation that firm age and firm size (rejecting Gibrat's Law) affect firm growth. Despite this tradition, and considerable progress in understanding the growth of small and/or new firms, many unanswered questions remain. This special issue takes stock of the current state of the art in the study of the growth of new and/ or small and medium-sized firms.

Small Business Economics explicitly encourages research from a broad spectrum of disciplines; in this special issue scholars from economics, management, engineering, and public policy throw light on the study of the growth of firms. All the papers are based on real-world evidence, which provides the path to genuine progress (cf. Simon 1991; Scherer 2001). Even though the papers often approach the analysis of the growth of firms from a different perspective, with different samples, and with different dependent variables (Table 1), the papers are so coherent in 
Table 1 The nature of firms studied and dependent variable

\begin{tabular}{|c|c|c|}
\hline Paper & Nature of firms & Dependent variables \\
\hline $\begin{array}{l}\text { Bonaccorsi and } \\
\text { Giannangeli }\end{array}$ & $\begin{array}{l}\text { Italian start-ups, representative } \\
\text { sample }\end{array}$ & $\begin{array}{l}\text {-Start-up employment size } \\
\text {-Probability of employment } \\
\text { growth }\end{array}$ \\
\hline $\begin{array}{c}\text { Fotopoulos and } \\
\text { Giotopoulos }\end{array}$ & Greek manufacturing firms & -Employment growth rate \\
\hline Park, Shin, and Kim & $\begin{array}{l}\text { South Korean manufacturing } \\
\text { firms }\end{array}$ & $\begin{array}{l}\text {-Firm survival } \\
\text {-Employment growth rate }\end{array}$ \\
\hline Leitner and Güldenberg & Austrian manufacturing SMEs & $\begin{array}{l}\text {-Average profitability } \\
\text {-Turnover growth } \\
\text {-Employment growth rate }\end{array}$ \\
\hline $\begin{array}{l}\text { Parker, Storey, and } \\
\text { Van Witteloostuijn }\end{array}$ & $\begin{array}{l}\text { Exceptionally fast-growing } \\
\text { British medium-sized firms }\end{array}$ & $\begin{array}{l}\text {-Turnover growth } \\
\text {-Firm size/survival }\end{array}$ \\
\hline
\end{tabular}

topic that the editors decided to group them into a special issue. ${ }^{1}$

Many studies prove that firm size and firm age are statistically related to firm growth (Geroski 1995; Sutton 1997; Audretsch et al. 2004). This does not necessarily improve our insight into the role of growth processes and strategies for firm growth, as firm size and firm age can be indicators for multiple mechanisms (e.g., economies of scale, learning effects, reputation effects). Notwithstanding this limited explanatory value, these are important dimensions in classifying the nature of firms. In Fig. 1 the firms studied in the different papers are positioned in a matrix, with firm age and firm size on the axes. Even though the focus is on "entrepreneurial firms" (see Van Praag and Versloot 2007), not all firms studied are young and/or small. With respect to rapidly growing firms (so-called gazelles) and their contribution to net employment growth in the economy, it appears that newness is a more important factor than small size (Henrekson and Johansson 2010). These gazelles are central in the papers by Henrekson and Johansson (2010) and Parker et al. (2010), while featuring in the paper by Bonaccorsi and Giannangeli (2010). However, new firms that grow to a substantial size are a small minority in the population of start-ups. Within this elite set of new growing firms, only a very small number become indistinguishable from incumbents and develop into industry leaders, such as Microsoft, SAP, or Google.

\footnotetext{
1 This issue is a special issue ex post; it was not intended and designed in advance, and all papers have gone through the regular review process.
}

Recent studies show that the fastest growing firms are driven by different factors from the more moderately growing firms (Coad and Rao 2008; Hölzl 2009; Stam and Wennberg 2009); nevertheless, predicting which new firms will develop into new industry leaders is an impossible exercise. However, what can be done is improving our measures and understanding of the relevant growth processes [see the papers by Parker et al. (2010), Leitner and Güldenberg (2010), Bonaccorsi and Giannangeli (2010), and Fotopoulos and Giotopoulos (2010)], and the role of firm strategies in the explanation of firm growth [see the papers by Parker et al. (2010), Leitner and Güldenberg (2010), and Park et al. (2010)]. In the light of this progress being made, it is remarkable that Gibrat's Law still plays such a prominent role in studies of firm growth.

\section{Gibrat's Law}

With the exception of the paper by Leitner and Güldenberg (2010)—which is completely positioned in the strategic management literature-the arguments made by all papers are positions relative to Gibrat's Law. The original interpretation of Gibrat's Law is that the size of units and measures of percentage growth are statistically independent (Gibrat 1931). In the context of the study of firm growth this means that growth rates should be independent of firm size (Sutton 1997). The Law can be tested in at least three different ways (Lotti et al. 2003). First, it might hold for all firms, including those that have exited during the period examined. Second, it might hold only for 
Fig. 1 Age and size of firms studied

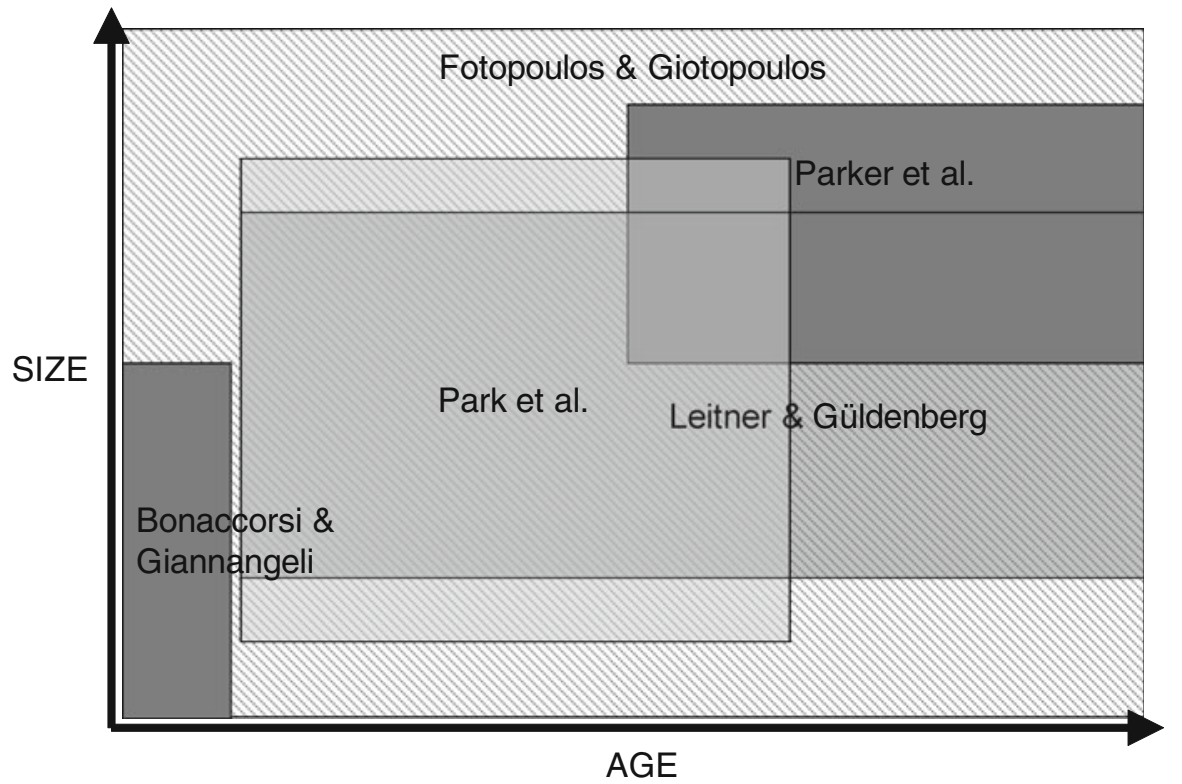

firms that survive over the entire time period. If survival is not independent of a firm's initial size, the empirical test can be affected by sample selection bias and estimates should take account of this possibility (especially since it is a stylized fact that the hazard rate for new and small firms is generally higher than for other firms). Third, Gibrat's Law might only apply to firms large enough to have overcome the minimum efficient scale of production in a given industry (which is, for example, smaller in the hospitality sector than in the manufacturing sector; see Audretsch et al. 2004). A broader interpretation of Gibrat's Law in economics is that corporate growth is a random process, not determined by structural firm or environmental characteristics. Predictions of the size (and growth) of the firm are conditional on (random) exogenous changes, and it follows that variations in the latter over time drive variations in the former (Geroski 2005). This might leave scholars of strategy with empty hands, or at best a null hypothesis to disconfirm.

Gibrat's Law turns out to be a null hypothesis that is rather easy to refute. From an empirical point of view, many studies, including some in this special issue, have found firm size and other variables to be statistically related to subsequent firm growth (Sutton 1997; Calvo 2006; Petrunia 2008). ${ }^{2}$ The main result

\footnotetext{
${ }^{2}$ See Lotti et al. (2003) and Audretsch et al. (2004) for a review of empirical studies.
}

from previous studies is that smaller and younger firms grow faster than larger and older firms, respectively, even when sample selection (especially the high exit rates of young and small firms) is controlled for (Lotti et al. 2003). Fotopoulos and Giotopoulos (2010) find that, for Greek manufacturing firms, Gibrat's Law is rejected for micro, small, and young firms (with an inverse relation between initial firm size and firm growth), while it is accepted for medium, large, and old firms. Parker et al. (2010) find that gazelle growth is significantly affected by a number of strategy variables (see also Mascarenhas et al. 2002), such as using customer surveys, selling to other businesses rather than to customers directly, and-more controversially-avoiding issuing shares to workers, directors or other outside investors, and refraining from developing new products. ${ }^{3}$ However, strategic best practices in one period do not automatically work in subsequent periods. Leitner and Güldenberg (2010) also find that strategy variables are related to long-term (10-year) growth of SMEs, and find no performance difference between SMEs that persist in their strategy over this period and SMEs that changed their generic strategy. Bonaccorsi and Giannangeli (2010) find that the growth process

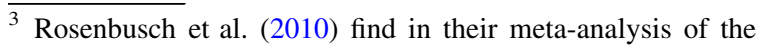
relation between innovation and SME performance that innovation has a stronger impact on the performance of younger firms than on more established SMEs.
} 
of micro start-ups is different from small and medium-sized start-ups, with the latter being more likely to grow following entry. This finding refines the contra-Gibrat's Law stylized fact that growth rates of firms tend to be negatively correlated with firm size by showing that the relation between firm size and firm growth is nonlinear: new micro firms are less likely to grow than new small and mediumsized firms, while small and medium-sized firms are more likely to grow than large firms. This might indicate that the traditional explanation for the rejection of Gibrat's Law, i.e., that young small firms have to expand in order to reach the minimum efficient scale of production in their industry, holds only for multiperson start-ups, while micro start-ups might survive on a small scale, perhaps due to the low growth aspirations and high nonmonetary income of their founders (Gimeno et al. 1997; Stam and Wennberg 2009). Finally there are two situations that cast even more doubt on the relevance of Gibrat's Law. First, even if Gibrat's Law seems to be confirmed, this might be due to omitted variables bias or measurement errors. Second, if firm size and age are shown to have no effect of firm growth, still many other variables might affect firm growth (see Leitner and Güldenberg 2010), disconfirming the hypothesis that firm growth is a fully random process.

An extension of Gibrat's Law is that firm growth is not correlated over time. An argument against this is that there are economies of growth (cf. Penrose 1959; Garnsey et al. 2006), which make the growth-growth sequence more likely than stagnation-growth or decline-growth. Arguments against growth persistence are of an empirical and normative nature: the persistence of growth would lead to a situation in which there will only be one big firm left in the economy, which is not what we perceive in reality, ${ }^{4}$ and such a monopoly situation is likely to have many harmful effects on economic progress. Empirical evidence can be found in favor of (Wagner 1992; Garnsey et al. 2006) and against (Almus and Nerlinger 2000; Coad 2007; Coad and Hölzl 2009) the persistence of growth. Fotopoulos and Giotopoulos (2010) find persistence of growth for micro and small firms, and for young firms in their sample of Greek manufacturing firms over the period 1995-2001,

\footnotetext{
${ }^{4}$ Diseconomies of scale set in at some point, and the firm has to spin out, outsource, or will be stripped into pieces.
}

while Parker et al. (2010) find that gazelles have difficulty sustaining their pace of growth.

\section{Future research}

What is the next step in the field of firm growth studies? One possible step would be to extract from the maze of results an integrated coherent view of how and why growth occurs in new and/or small firms (cf. Storey 1994; Wiklund et al. 2009). The question is how broad or narrow the application of such a view should be, given the range of growth modes (Lockett et al. 2010; McKelvie and Wiklund 2010), growth measures (Coad 2009; Shepherd and Wiklund 2009), types of firms and contexts (Davidsson and Henrekson 2002), and periods of growth. This specification might, for example, exclude firm growth for a very short (less than 1 year) or very long (more than 10 years) term, and should make a distinction between, for example, high- and low-technology firms (Stam and Wennberg 2009) and/or the phase of the relevant industry lifecycle (Henrekson and Johansson 2010).

At least two major issues deserve further attention in the future: how to deal with randomness and strategy (i.e., not the traditional dichotomy of randomness $o r$ strategy) in the explanation of firm growth, and what kind of growth (path) is to be explained. These two issues are interdependent in many ways, for example, as the effect of randomness is measured differently in variance of growth studies than in the study of growth paths of firms, and strategy is likely to work out differently over the life course of firms.

The randomness of growth that seems to be assumed in Gibrat's Law and neoclassical firm growth theories (Geroski 2005) is not something to be disregarded. We should be suspicious of research that explains more than half of the variance of growth, given idiosyncratic variation, chance, and unavoidable measurement error (Davidsson 2004). On the other hand, the explanatory power of our models should not be so small (Coad 2009) that we are just debating a very marginal part of the growth process. Given that random effects are dominant in the explanation of firm growth (and firm survival, see Frankish et al. 2008), our challenge is to better understand how entrepreneurs, managers, finance suppliers, and governments should respond. A reappraisal of randomness beyond the Gibrat interpretations requires an improvement 
and expansion of the set of explanatory variables in empirical research. Such a reappraisal of randomness should take into account the historical and ecological situations in which randomness is dealt with. In the historical context, dependent variables can turn into independent variables, and processes of experiential learning, sequences of activities, and path dependence become center stage (cf. Phelps et al. 2007; Levie and Lichtenstein 2010). In the ecological context, (random) external shocks and more gradual changes in competition, institutions, and technologies are central. The historical accumulation of resources might explain the differential reaction and performance of firms that face similar external shocks: firm-specific capabilities lead to different levels of resilience and productive opportunity sets of firms (cf. Penrose 1959; Cohen and Levinthal 1990).

Understanding what drives the sustained or erratic growth of firms over many years remains a key issue. In addition to taking into account different modes of growth, we should be aware that, next to the growth of the firm as a hierarchy, other forms of governance might also lead to a similar growth of economic activities. New technologies and/or institutions make it possible to expand economic activities in networked coalitions of self-employed. Other institutions constrain growth in one firm, and make it more likely to create and expand new economic activities in different firms within a business group (Iacobucci and Rosa 2010). On the one hand, a firm is "just" a legal entity to govern economic activities, one governance form out of a menu of governance choices. If the network form of governance becomes more effective, then the hierarchy (and its growth) might be less relevant as a unit of analysis (Powell 1990; Teece 1992). On the other hand, firms are communities of individuals that collectively have the capability to produce economic value in a way that cannot be realized by "just" combining the individual parts (Penrose 1959; Kogut and Zander 1992). This means that, for certain future returns, longer-term investments on a relatively large scale have to be made, for which the firm still seems to be the most effective form of governance. The extent to which economies of scale, economies of time, and economies of scope (related variety) can best be reaped within a firm, or for example in a constellation of firms within a geographically confined region (cf. Frenken and Boschma 2007), remains a question to be answered. $^{5}$
The search for necessary mechanisms and contingent conditions for the growth of firms is not likely to be saturated in the near future, given the changes in economy and society, which enable new ways of organizing old and new economic activities. The study of firm growth is likely to remain a fascinating area of research.

Acknowledgments The author would like to thank David Storey, Magnus Henrekson, and Johan Wiklund for useful comments and suggestions, and Elizabeth Garnsey for numerous discussions on the growth of the firm.

Open Access This article is distributed under the terms of the Creative Commons Attribution Noncommercial License which permits any noncommercial use, distribution, and reproduction in any medium, provided the original author(s) and source are credited.

\section{References}

Almus, M., \& Nerlinger, E. A. (2000). Testing Gibrat's Law for young firms-empirical results for West Germany. Small Business Economics, 15, 1-12.

Audretsch, D. B., Klomp, K., Santarelli, E., \& Thurik, A. R. (2004). Gibrat's Law: Are the services different? Review of Industrial Organization, 24, 301-324.

Beaudry, C., \& Swann, G. M. P. (2009). Firm growth in industrial clusters of the United Kingdom. Small Business Economics, 32(4), 409-424.

Bonaccorsi, A., \& Giannangeli, S. (2010). One or more growth processes? Evidence from new Italian firms. Small Business Economics. doi:10.1007/s11187-008-9131-0.

Calvo, J. L. (2006). Testing Gibrat's Law for small, young and innovating firms. Small Business Economics, 26, 117-123.

Coad, A. (2007). A closer look at serial growth rate correlation. Review of Industrial Organization, 31, 69-82.

Coad, A. (2009). The growth of firms: A survey of theories and empirical evidence. Cheltenham: Edward Elgar.

Coad, A., \& Hölzl, W. (2009). On the autocorrelation of growth rates. Journal of Industry, Competition and Trade, 9(2), 139-166.

Coad, A., \& Rao, R. (2008). Innovation and firm growth in high-tech sectors: A quantile regression approach. Research Policy, 37, 633-648.

\footnotetext{
5 Several studies in small business economics consider the effect of regional clusters on firm growth (see Park et al. 2010, and also Beaudry and Swann 2009; Maine et al. 2010; Wennberg and Lindqvist 2010). However, another avenue of research might be the question of how firms grow, or how the expansion of economic activities is governed differently in highly urbanized or specialized regions than in other regional contexts.
} 
Cohen, W. M., \& Levinthal, D. A. (1990). Absorptive capacity: A new perspective on learning and innovation. Administrative Science Quarterly, 35, 128-152.

Davidsson, P. (1991). Continued entrepreneurship: Ability, need, and opportunity as determinants of small firm growth. Journal of Business Venturing, 6, 405-429.

Davidsson, P. (2004). Researching entrepreneurship. New York: Springer.

Davidsson, P., \& Henrekson, M. (2002). Determinants of the prevalence of start-ups and high-growth firms. Small Business Economics, 19(2), 81-104.

Davidsson, P., Delmar, F., \& Wiklund, J. (2006). Entrepreneurship and the growth of firms. Cheltenham: Edward Elgar.

Evans, D. S. (1987). Tests of alternative theories of firm growth. Journal of Political Economy, 95, 657-674.

Fotopoulos, G., \& Giotopoulos, I. (2010). Gibrat's Law and persistence of growth in Greek manufacturing. Small Business Economics. doi:10.1007/s11187-008-9163-5.

Frankish, J. S., Roberts, R. G., Storey, D. J. (2008). Do entrepreneurs really learn? Evidence from bank data. Warwick Business School's Small and Medium Sized Enterprise Centre Working Papers, No. 98. Warwick: University of Warwick.

Frenken, K., \& Boschma, R. A. (2007). A theoretical framework for evolutionary economic geography: Industrial dynamics and urban growth as a branching process. Journal of Economic Geography, 7(5), 635-649.

Garnsey, E., Stam, E., \& Heffernan, P. (2006). New firm growth: Exploring processes and paths. Industry and Innovation, 13, 1-20.

Geroski, P. (1995). What do we know about entry? International Journal of Industrial Organization, 13, 421-440.

Geroski, P. A. (2005). Understanding the implications of empirical work on corporate growth rates. Managerial and Decision Economics, 26(2), 129-138.

Gibrat, R. (1931). Les inégalités économiques: applications: aux inégalités des richesses, à la concentration des entreprises, aux populations des villes, aux statistiques des familles, etc.: d'une loi nouvelle: la loi de l'effet proportionnel. Paris: Sirey.

Gimeno, J., Folta, T., \& Woo, C. (1997). Survival of the fittest? Entrepreneurial human capital and the persistence of underperforming firms. Administrative Science Quarterly, 42, 750-783.

Henrekson, M., \& Johansson, D. (2010). Gazelles as job creators: A survey and interpretation of the evidence. Small Business Economics. doi:10.1007/s11187-009-9172-z.

Hölzl, W. (2009). Is the R\&D behaviour of fast-growing SMEs different? Evidence from CIS III data for 16 countries. Small Business Economics, 33(1), 59-75.

Iacobucci, D., \& Rosa, P. (2010). The growth of business groups by habitual entrepreneurs: The role of entrepreneurial teams. Entrepreneurship Theory and Practice, 34(2), 351-377.

Kogut, B., \& Zander, U. (1992). Knowledge of the firm, combinative capabilities, and the replication of technology. Organization Science, 3, 383-397.

Leitner, K.-H. \& Güldenberg, S. (2010). Generic strategies and firm performance in SMEs: A longitudinal study of
Austrian SMEs. Small Business Economics. doi:10.1007/ s11187-009-9239-x.

Levie, J., \& Lichtenstein, B. B. (2010). A terminal assessment of stages theory: Introducing a dynamic states approach to entrepreneurship. Entrepreneurship Theory and Practice, 34(2), 317-350.

Lockett, A., Wiklund, J., Davidsson, P., Girma, S. (2010). Organic and acquisitive growth: Re-examining, testing and extending Penrose's growth theory. Journal of Management Studies. doi:10.1111/j.1467-6486.2009.00879.x.

Lotti, F., Santarelli, E., \& Vivarelli, M. (2003). Does Gibrat's Law hold among young, small firms? Journal of Evolutionary Economics, 13(3), 213-235.

Maine, E. M., Shapiro, D. M., \& Vining, A. R. (2010). The role of clustering in the growth of new technology-based firms. Small Business Economics, 34(2), 127-146.

Mascarenhas, B., Kumaraswamy, A., Day, D., \& Baveja, A. (2002). Five strategies for rapid firm growth and how to implement them. Managerial and Decision Economics, 23, 317-330.

McKelvie, A., \& Wiklund, J. (2010). Advancing firm growth research: A focus on growth mode instead of growth rate. Entrepreneurship Theory and Practice, 34(2), 261-288.

Park, Y., Shin, J., Kim, T. (2010). Firm size, age, industrial networking, and growth: A case of the Korean manufacturing industry. Small Business Economics. doi: 10.1007/s11187-009-9177-7.

Parker, S. C., Storey, D. J., Van Witteloostuijn, A. (2010). What happens to gazelles? The importance of dynamic management strategy. Small Business Economics. doi: 10.1007/s11187-009-9250-2.

Penrose, E. (1959). The theory of the growth of the firm. Oxford: Oxford University Press.

Petrunia, R. (2008). Does Gibrat's Law hold? Evidence from Canadian retail and manufacturing firms. Small Business Economics, 30(2), 201-214.

Phelps, R., Adams, R., \& Bessant, J. (2007). Life cycles of growing organizations: A review with implications for knowledge and learning. International Journal of Management Reviews, 9, 1-30.

Powell, W. W. (1990). Neither market nor hierarchy: Network forms of organization. Research in Organizational Behavior, 12, 295-336.

Rosenbusch, N., Brinckmann, J., Bausch, A. (2010). Is innovation always beneficial? A meta-analysis of the relationship between innovation and performance in SMEs. Journal of Business Venturing. doi:10.1016/j.jbusvent.2009.12.002.

Scherer, F. M. (2001). Assessing progress in research on industrial evolution and economic growth: A review article. Small Business Economics, 16(3), 237-242.

Shepherd, D., \& Wiklund, J. (2009). Are we comparing apples with apples or apples with oranges? Appropriateness of knowledge accumulation across growth studies. Entrepreneurship Theory and Practice, 33, 105-123.

Simon, H. A. (1991). Organizations and markets. Journal of Economic Perspectives, 5(2), 25-44.

Stam, E., \& Wennberg, K. (2009). The roles of R\&D in new firm growth. Small Business Economics, 33, 77-89.

Storey, D. J. (1994). Understanding the small business sector. London: Routledge. 
Sutton, J. (1997). Gibrat's legacy. Journal of Economic Literature, 35(1), 40-59.

Teece, D. J. (1992). Competition, cooperation, and innovation. Organizational arrangements for regimes of rapid technological progress. Journal of Economic Behavior \& Organization, 18, 1-25.

Van Praag, C. M., \& Versloot, P. H. (2007). What is the value of entrepreneurship? A review of recent research. Small Business Economics, 29(4), 351-382.

Vivarelli, M. (2007). Entry and post-entry performance of newborn firms. London: Routledge.
Wagner, J. (1992). Firm size, firm growth, and the persistence of chance: Testing Gibrat's Law with establishment data for lower Saxony, 1978-1989. Small Business Economics, 4, 125-132.

Wennberg, K., \& Lindqvist, G. (2010). The effect of clusters on the survival and performance of new firms. Small Business Economics, 34(3), 221-241.

Wiklund, J., Patzelt, H., \& Shepherd, D. A. (2009). Building an integrative model of small business growth. Small Business Economics, 32, 351-374. 